\title{
Mecanismos de construção da polifonia na obra O jogador de Dostoiévski
}

\author{
Danilo Chiovatto SERPA
}

RESUMO: Procuramos herdar a noção bakhtiniana de polifonia e descrevê-la semioticamente. Examinaremos mecanismos de construção do sentido do plano do conteúdo, a articulação destes com a forma do gênero, passando pelo percurso narrativo. Das relações imanentes do sentido, a polifonia será descrita. Serão feitos apontamentos sobre a sátira menipéia e a carnavalização.

PALAVRAS-CHAVE: polifonia; Dostoiévski; O Jogador; sátira menipéia; carnavalização

\begin{abstract}
We want to inherit the Bakhtin's concept of poliphony and describe it semiotically. We will examine meaning construction mechanisms of the subject plan, and their articulation with the genre structure, going through the narrative course. From the lasting meaning relations, poliphony will be described. There will be notes about Menippean satire and "carnivalisation".
\end{abstract}

KEYWORDS: polyphony; Dostoievsk; The Player; Menippean satire; "carnivalisation" 


\section{Resumo parafrástico do livro "O jogador”, de Dostoievski:}

Alexei Ivanovitch, protagonista e narrador em primeira pessoa de sua própria história, é tutor dos filhos de um general russo. Ele acompanha a comitiva desse general que se hospeda em Roulletenburg, Alemanha. O general é parte de uma aristocracia decadente, está com sérios problemas financeiros e espera avidamente a morte de uma tia que possui muito dinheiro e bens (a "avozinha" de Paulina), porque ele espera herdálos.

Na comitiva encontram-se, principalmente, Paulina Alexandrovna, com quem Alexei vive uma relação de amor e ódio. Dois franceses: Dês Grieux, com quem o general possui dívidas e por quem Paulina tem interesses, e Blanche, mulher interessada no dinheiro que supostamente o general herdaria: em Roulettenburg também se encontra o inglês Mr. Astley, amigo de Alexei.

A tia do general vai até Roulettenburg e gasta quase toda sua fortuna no jogo de roleta e Alexei, em um golpe da sorte, fica rico com o mesmo jogo. Dês Grieux abandona o general na pobreza, Blanche e Alexei vão para Paris gastar a fortuna ganha por este e Paulina fica doente (começa a ter espasmos de loucura).

Alexei rapidamente gasta o dinheiro que ganhou na roleta e separa-se de Blanche, vaga pelos cassinos da Europa e torna-se um jogador de roleta. No ultimo capítulo do livro Mr. Astley encontra-o e tenta persuadi-lo para parar com o jogo, dizendo que talvez Paulina o ame.

\section{Introdução: Recuperando Bakhtin}

"Todos os textos supõem na enunciação sujeitos alterados por quereres, deveres, poderes, saberes; sujeitos dados pela falta de um objeto de desejo a ser buscado" (DISCINI: 2005, p. 35).

Partindo desse pressuposto me proponho uma análise do discurso e do sujeitonarrador-protagonista da própria história, Alexei Ivanovitch, do romance $O$ jogador, de Dostoiévski.

"Efetua-se a narração em Dostoiévski da primeira pessoa, na forma de confissão, ou da pessoa do autor-narrador" (BAKHTIN: 1981, p.31).

No início do romance temos a indicação: "O Jogador (do diário de um jovem)". Uma das marcas do gênero "diário" é "o discurso voltado para o registro íntimo do diaa-dia, organizados em tom confessional, o que supõe o simulacro de um mundo que, além de privado, é estabelecido por meio da prevalência dos "estados de alma" (DISCINI: 2005, p. 311). As características do gênero "diário" tendem a diminuir o papel do narratário na enunciação.

Bakhtin dá a Dostoiévski o título de "criador do romance polifônico". A polifonia é um conceito emprestado da música, é o encontro de várias vozes, música que tem duas ou mais partes (ou vozes) soando de forma simultânea. No conceito literário, polifonia é a multiplicidade de vozes depreensíveis de um texto. Essas vozes não são dadas em diálogo representado por discurso direto, essas vozes são pontos de vista, são modos de presença no mundo. Para o filósofo russo, no discurso de Dostoiévski os 
personagens são ideólogos, defendem vozes que não necessariamente são as do autor. Os personagens possuem independência e espaço para a realização de seus discursos, porém eles, entre eles mesmos, são conflitantes, não possuem meios de anular ou negar o discurso do outro, seus discursos são plenivalentes.

Nesse ponto o romance de Dostoiévski é dialógico, mas não no sentido dramático, em que as vozes convergem para um fim, que

“impõe-se rigoroso encadeamento causal, cada cena sendo a causa da próxima e esta sendo o efeito da anterior" (ROSENFELD: 2002, p. 30).

O discurso aqui é divergente de si mesmo, as vozes se opõem e não há resolução, não há conclusão, o sujeito se dá pela incompletude (e isso pode ser estendido à obra) e não pelo acabamento. A própria unidade é fragmentária. O romance de Dostoiévski é a expressão em sentido literário da polifonia: o entrechoque das vontades.

O ser, em Dostoiéski, possui autonomia em sua visão de mundo e também um posicionamento em relação a ele. $\mathrm{O}$ escritor russo, portanto, é um arauto de um outro épico, um antiépico, uma nova forma do gênero. $\mathrm{O}$ romance de Dostoiévski descende do gênero cômico trágico, de linha carnavalesca. Como carnavalesca entendem-se aqui os vários e as variadas formas de realização dos ritos dionisíacos. Rito: experimentação do mito. E mito ainda entendido como a verdade revelada pelos deuses desde os tempos imemoriais. Ou seja, carnaval como fantasia que leva à experimentação da verdade. Dionísio como encarnação das forças ctônicas, da destruição e do renascimento, da dissolução (sparagmós); o deus mutável, o deus que oblitera o afável olho da verdade para não a ver, para a sentir. A idéia que não teme a lama, o deus subterrâneo, o truschóbiy naturalsm, o naturalismo do submundo.

O estilo de Dostoiévski também remonta ao "diálogo socrático", em que a revelação da verdade é feita de forma dialógica. Sócrates não é dono de uma verdade acabada, esta é construída na interação, para ter valor deve ser atualizada. É a famosa cisão no mundo grego entre a autoridade inquestionável do mito e o questionamento filosófico, racional. O mito continha a verdade revelada, estática, imutável, válida desde sempre para todo o sempre. A filosofia socrática, florescida na época da democracia ateniense, só sabia que nada sabia. A verdade filosófica deve ser fundamentada, as leis questionadas. Porém, em uma sociedade baseada no fundamento (Gundlage), o último fundamento é um abismo (Abgrund), não pode ser fundamentalista ${ }^{1}$. Uma grande verdade acabada, imutável, se assemelharia à verdade dos mitos. A divergência de vozes tem como resultado a famosa "ironia socrática". É o riso que ultrapassa as prisões do paradoxo, que vence a limitação do humano:

"o riso é uma posição estética determinada diante da realidade mas intraduzível na linguagem lógica" (BAKHTIN: 1981, p.142). "Cabe ressaltar que as concepções socráticas da natureza dialógica da verdade se assentavam na base carnavalesco-popular do gênero diálogo socrático e determinavam-lhe a forma ${ }^{2}$, mas nem de longe encontravam sempre expressão no próprio conteúdo de alguns diálogos. $\mathrm{O}$ 
conteúdo adquiria freqüentemente caráter monológico, que contradizia a idéia formadora do gênero" (BAKHTIN: 1981, p.94).

Segundo Bakhtin, as obras de Dostoiévski descendem de um gênero romanesco da tradição dos romances de aventura, contrastando com os romances de linha biográfica, estes representados por autores como Tolstoi. Se neste gênero o herói é caracterizado, definido socialmente, personalizado e cumpre suas tarefas com decoro, naquele o herói é descaracterizado, indefinido socialmente, mas com sede de personalização. Procura realizar tarefas humanas como a auto conservação, tem sede de vitória e criação, quer ter posse e amor sensual. Mas é inacabado como próprio ser.

$\mathrm{O}$ gênero cômico-sério também remonta à sátira menipéia. Este gênero não apresenta exigências, como diz Bakhtin, quanto à verossimilhança externa. Homens e idéias separados por séculos se encontram para se confrontar. São apresentadas situações que provocam a experimentação da idéia, representam-se inusitados estados psíquicos morais, freqüentemente a loucura. O gênero porta a polêmica social, aproximando-se do cotidiano, do "jornalístico".

"Ela se formou numa época de luta tensa entre inúmeras escolas e tendências religiosas e filosóficas heterogêneas, quando as discussões em torno das 'últimas questões' da visão de mundo se converteram em fato corriqueiro entre todas as camadas da população". (BAKHTIN: 1981, p.102).

Para este presente estudo a obra tomada como modelo de sátira menipéia será o "Diálogo dos mortos" de Luciano de Samosáta, que junta o gênero do diálogo com o cômico. "Diálogo dos mortos" tem como personagens principais os filósofos cínicos Diógenes e Menipo. Estes, no Hades, interrogam mortos ilustres como os reis Midas ${ }^{3}$, Creso $^{4}$, Sardanápalo ${ }^{5}$, o adivinho Tirésias e filósofos, como Sócrates. Sempre colocam em xeque as posições de cada um no mundo.

"Diálogo dos mortos" é uma obra do século II d.C., época da chamada segunda sofística, movimento que se caracteriza principalmente pela nostalgia do estilo grego clássico. Se a própria constituição da língua russa é um fator de polifonia, a época da segunda sofística foi um tempo de grande valorização da língua grega, gerando uma curiosa espécie de bilingüismo: O imperador romano Marco Aurélio, por exemplo, escreveu sua obra "Pensamentos" em grego Ático.

O século II depois de Cristo também apresenta uma outra importante característica: é a época da emergência de uma nova religião, o cristianismo. Os antigos costumes estavam agonizantes e abrindo espaço para uma nova crença e, conseqüentemente, uma nova concepção da realidade. Essa degradação das antigas crenças, das antigas verdades e concepções de mundo, sem dúvida, geraram uma exaltação do relativismo, a própria sofistica já é uma pregação do relativismo. As "grandes questões" são abandonadas, a sátira à condição humana é o que resta. No "Diálogo dos mortos", Menipo, a convite de Diógenes, desce ao Hades (realizando um suicídio, que é visto como um desprezo à vida) para zombar dos mortos. Menipo é o único que não paga o óbulo a Caronte, o filósofo é também o único que canta ao atravessar o rio, enquanto os outros mortos choram. 
Interessante é que a época em que Dostoiévski escreve, a segunda metade do século XIX, é a época da morte, da agonia, do deus cristão. Teorias cientificistas como o darwinismo e o materialismo histórico, por exemplo, abalaram crenças religiosas e pouco depois se proclamaria a morte de Deus. Novamente as certezas, as "verdades eternas" e "imutáveis" eram abaladas, discussões sobre a origem do homem e o seu futuro desenvolvimento histórico eram corriqueiras e populares entre as pessoas dessa época. O que poderia, agora, ser proclamado como certo, como imutável?

A idéia de efemeridade das coisas se faz presente no "Diálogo dos mortos": observamos Menipo zombando das lamentações de Creso, Sardanápalo e Midas pelas riquezas e luxos terrenos perdidos. No diálogo $\mathrm{V}$ o filósofo cínico discute com Hermes a efemeridade da beleza chegando mesmo, no diálogo XXX, a não conseguir diferenciar, no Hades, quem é Nireu, guerreiro famoso pela beleza, de Tersites, um disforme, dizendo que no Hades não há diferença, eles estão em pé de igualdade. Menipo, em seu encontro com Tirésias, ridiculariza os profetas e as profecias e, no diálogo XX, intitulado "Caronte, Hermes, Menipo e Vários Mortos", vemos os mortos se "despindo" para fazer menos peso e poder entrar na barca de Caronte: os mortos devem se desfazer da soberba e da beleza. Porém, liberdade, franqueza, ausência de tristeza, nobreza e riso, são leves e fáceis de transportar na barca. Aqui podemos perceber os valores da filosofia cínica.

“Os 'mortos atuais' são grãos estéreis lançados na terra mas incapazes de morrer (ou seja, de livrar a si mesmo de suas próprias impurezas, de colocar-se acima de si mesmo) ou renascer renovados (ou seja, dar fruto)" (BAKHTIN: 1981, p.127).

No rito dionisíaco carnavalesco "o nascimento é prenhe de morte" (BAKHTIN: 1981, p.107) e, "o renascimento é a culminância da vida carnavalesca" (BAKHTIN: 1981, p.112). É preciso a morte para um novo nascimento. Podemos aqui citar os "Irmãos Karamazov" de Dostoiévski, quando um visitante misterioso pergunta ao stárietz ${ }^{6}$ Zossima (personagem do romance) quem escreveu:

"Em verdade, em verdade vos digo: se o grão de trigo, caindo na terra, não morrer, fica ele só; mas se morrer, produz muito fruto", e ele responde: "O Espírito Santo" (DOSTOIÉVSKI: 1976. p. 281).

É a derrocada do cristianismo e dos próprios ritos carnavalescos. Dostoiévski e os representantes da sátira menipéia apresentam uma curiosa comunhão à priori de aspirações. Assim, podemos encontrar semelhanças entre obras separadas por um grande espaço temporal e de constituições tão diferentes.

Nos heróis de Dostoievski a autoconsciência é plena, mas incompleta, pois não contêm o reconhecimento, a identificação, a fusão com a consciência do outro. Mikhail Bakhtin publicou "Problemas da poética de Dostoiévski" no ano de 1929, na antiga União Soviética. A revolução comunista de 1917 abriu uma época de esperança, não só para o povo mas também para os pensadores: seria o sonho da igualdade entre os homens finalmente alcançado? No início da década de vinte as artes soviéticas conheceram um período áureo, mas já no final da década a ditadura de Stalin se fez 
sentir: muitas obras de vanguarda foram proibidas de circular. O próprio Bakhtin passou quase praticamente a vida inteira impedido de publicar. Bakhtin, ao retomar um autor do século XIX na segunda década do século XX, frisando o diálogo, o polifônico, a multiplicidade, não estaria soltando um grito contra a intolerância, o centralismo, a homogeneização? Quando a verdade é apenas pessoal cria-se um tipo de solidão especial, um solipsismo ético. ${ }^{7}$

Uma das características do romance polifônico, como conseqüência do inacabamento orgânico da narrativa, é a presentificação permanente. $O$ tempo apresenta-se em sua extensividade máxima, chegando às barreiras da eternidade. $\mathrm{O}$ tempo é, aqui, um componente essencial: o tempo destrói, devora tudo. Consumindo sempre, derrubando verdades, traz a desolação, mas a esperança no próximo minuto. Como uma roleta: tudo pode ser feito e desfeito em um minuto.

"O tempo, representado no limiar das transformações vitais, apresenta-se como realidade (des)construída.” (DISCINI: 2006).

Não é à toa que no "Diálogo dos mortos", diálogo VII, apresenta-se a figura de Tântalo, rei da Lídia castigado por Zeus. Tântalo quer beber água, mas ela evapora no momento em que ele vai bebê-la. O rei quer comer, mas também é impedido e não consegue. Representa-se uma ambição que fracassa no momento de ser satisfeita. E Menipo diz: "Tântalo, isso faz parte da sentença: o desejo ardente de bebida, mesmo sem necessidade". Tântalo tem medo da sede e não da bebida. O diálogo XX também apresenta as figuras de Ixion e Sísifo: imagens de um castigo eterno, esforço inútil. Menipo zomba desse eterno esforço em vista de algo. Olhar para o Tempo é ver um desfile de aspirações e decepções do homem em torno dos "grandes ideais", que quando degenerados criam amarras para a liberdade, a realização e a felicidade do homem. E Bakhtin, que deu a Dostoiévski o título de criador do romance polifônico também classifica como polifônico "O mito de Sísifo" de Camus, uma obra filosófica. "Problemas da poética de Dostoiévski", em aliança com as sátiras menipéias e os romances de Dostoiévski são obras que procuram pensar a condição humana no limiar. E também a carnavalização é um aliado importante: o carnaval é a época em que se debilitam a seriedade retórica unilateral, a univocidade e o dogmatismo.

\section{0 inferno carnavalesco de Alexei}

Assistimos a uma degradação da cosmovisão carnavalesca nos tempos modernos: "a cosmovisão carnavalesca não diz respeito à 'concepção espetaculosateatral do carnaval, bastante característica dos tempos modernos', como alerta Bakhtin. A cosmovisão carnavalesca diz respeito, segundo essa fonte, a 'uma grandiosa cosmovisão universalmente popular dos milênios passados"” (DISCINI: 2006). O estudioso russo aponta também, como uma das características mais marcantes da carnavalização a destronalização dos poderosos.

A degeneração da cosmovisão carnavalesca conduz a um enfraquecimento da representação do grotesco nas estéticas filosóficas e manifestações literárias. Grottesco, palavra derivada do substantivo grotta (gruta), pois no século XV, uma imagem encontrada em uma terma subterrânea de Roma reunia representações vegetais, animais 
e humanas que se transformavam e se confundiam entre si, tal imagem representando a transmutação das formas acabou por ser a expressão do eterno inacabamento da existência. Esse universo grotesco existiu por toda Antiguidade Clássica, Idade Média e Renascimento.

"Ao tocar nos séculos posteriores àquele de Rabelais, Bakhtin afirmará então que, a partir do século XVII, certas formas do grotesco começam a degenerar em 'caracterização estática e estreita da pintura de costumes, como consequiência da limitação específica da concepção burguesa de mundo"” (DISCINI: 2006).

Se o carnavalesco tem como característica definidora o destronamento dos poderosos, as imagens grotescas, que representam o mutável, o inacabado, corroboram com a visão e percepção de mundo dado em relação ao rebaixamento do poder. Mas o destronamento requer um espaço próprio para a sua realização: no Renascimento e nos tempos anteriores a ele, o espaço carnavalesco do destronamento era a praça pública. Ali, no lugar público, em que todos se expõem a todos, era onde o poder centralizador, unilateral, perdia seu estatuto de verdade e legitimação para ser descaracterizado, transformando a seriedade cotidiana em riso estridente. É no espaço público que se desenrolam as aventuras de Gargântua e Pantagruel, de Rabelais.

A sátira menipéia mostra-nos, nos "Diálogos dos Mortos", de Luciano de Samosáta, uma solução diferente para a realização do destronamento: ele é feito no Hades, no espaço infernal dos gregos, no reino dos mortos. Ou seja, em um lugar fora dos valores cotidianos "normais". No mundo dos mortos os valores são invertidos, os poderes ridicularizados, e a idéia pode ser experimentada em sua concretude. Dostoiévski, homem do século XIX, terá de encontrar (e efetivamente encontrou) uma solução diferente para a experimentação da verdade e o destronamento do poder.

"O topos burguês (...) como elemento semântico histórico, não se coaduna com o discurso do realismo renascentista. Entretanto esse mesmo topos, por meio de uma variação do ritual de coroação e destronamento, pode transformar-se em espaço carnavalizado. Nesse topos, tal como tratado pela poética de Dostoiévski, diz Bakthin que 'por um instante as pessoas se vêem fora das condições habituais de vida, como na praça pública carnavalesca ou no inferno, e então se revela um outro sentido - mais autêntico - delas mesmas e das relações entre elas"” (DISCINI: 2006).

Dostoiévski, com seu romance polifônico, leva a representação do cotidiano e as ações dos personagens para o limiar de suas condições, assim o próprio cotidiano se transforma no inferno carnavalesco, o espaço privado burguês torna-se praça pública.

Vemos no romance $O$ jogador o hotel da cidade de Roulettenburg, que hospeda a comitiva do patrão general de Alexei, abrigando cenas de escândalo e comportamentos excêntricos: em um jantar formal Alexei (empregado) dá suas razões que são divergentes das do seu patrão, a "avozinha" de Paulina, ao perder dinheiro na roleta, volta para o hotel e distribui as suas "verdades" para quem quer que ela deseje: "retirem-se, seus demônios! Por que se metem? Por que este barba de bode está na minha frente?, gritou para Dês Grieux. E tu, periquita, o que desejas?, disse em direção 
de Blanche." O próprio cassino onde se joga roleta é um espaço em que todos, submetidos ao acaso, se igualam. "Em frente do local onde os veículos estacionavam para deixar as pessoas na aléia que leva ao cassino", Alexei, incitado por Paulina, insulta uma baronesa e causa um escândalo. Assim, os personagens do limiar, são levados a viver, cotidianamente, um inferno carnavalesco. ${ }^{8}$

“Limite vs. limiar (...) o pólo do limiar, correspondente ao inacabamento, opõese ao do limite, correspondente ao fechamento. O limiar sustenta a carnavalização nos discursos polifônicos. Fala-se agora de uma forma alterada de inacabamento, se tomarmos como parâmetro a imagem grotesca rabelaisiana. Em Rabelais temos o inacabamento em função do riso estridente; em Dostoiévski esse efeito estará em função do cômico-sério e do riso reduzido" (DISCINI: 2006).

Novamente, a representação da realidade terá de se (re)articular para dar conta das mudanças dos processos da vida. Tanto que a própria figura do narrador, caracterizado tradicionalmente como o experiente, aquele que sabe, é colocado em questão na narração de $O$ jogador, o narrador duvida de sua própria autoridade e de seu próprio saber (a função narrador-personagem ampara tal problemática):

(DOSTOIEVSKI: 1998, pág 142).

“Com a corroboração do não-saber do narrador (...) confirma-se como semanticamente inacabado o próprio passado (...) por meio da utilização de tais recursos, narrador e passado narrado são mantidos na ambigüidade carnavalesca profunda”. (DISCINI: 2006).

A multiplicidade de vozes, que caracteriza a polifonia é também viabilizada pelo próprio enfraquecimento da voz do narrador. Tudo isso é reflexo do problema da própria constituição de um sujeito (eu) em um mundo cada vez mais dominado pela impessoalidade. Os romances polifônicos de Dostoiévski já prenunciam as características marcantes da arte do século XX: a grande ruptura entre o ser e o mundo pela crescente fragmentação do sujeito e a sua impotência diante da realidade, a massificação dos produtos e a mecanização da vida levam a uma crise da perspectiva, a uma arte dada pelo não acabamento, pelo fragmentário. A ironia é uma forma indicativa dessa instabilidade e fragmentação do sujeito, o riso não se dá de maneira totalmente regeneradora, ela revela o desejo de reordenação da realidade, da reintegração do homem com a vida. O sentido de vida não se dá mais conhecida pelo sujeito, não é mais captado por ele. A própria vontade é levada à sua potência máxima, mas a combinação e o entrechoque delas (polifonia entrechoque de vontades) não conduz a nenhum norte. A possibilidade de uma épica em seu sentido tradicional é ceifada, até mesmo pela própria consciência de traição da memória. Eis porque atualmente a constituição de uma épica em seu sentido tradicional não é mais possível.

Vemos então os personagens do limiar dos romances polifônicos em uma complexa tentativa de se constituir no mundo, de efetivamente ser/estar no mundo. " $\mathrm{O}$ 
herói com autonomia de voz e constituído como avesso à biografia 'no sentido do ido e do plenamente vivido'; o herói carnavalizado" (DISCINI: 2006). E é a contradição interior que dá azo para o inacabamento da própria existência:

"para heróis ancorados no limite, Dostoiévski não dedica nem o paraíso nem o inferno carnavalescos. A eles é reservada a ironia” (DISCINI: 2006).

As cenas de escândalo destroem a integridade épica do mundo. É interessante aqui notar a concepção de "verdade artística" proposta por Bakhtin, para rebater as criticas feitas a Dostoiévski quanto a (in)verossimilhança das cenas de escândalo. Além da noção de verdade artística Bakhtin se apóia na noção de carnavalização interna. Ambas se sustentam em comunhão. A linha carnavalesca remete à experimentação da verdade, assim as aventuras são motivadas no sentido de experimentar uma idéia e "no rastro da provocação e da experimentação filosófica ancora-se a verdade carnavalizada". Isso é permitido no romance polifônico com o tempo e o espaço projetados para o limiar. A contradição do ser, a não-coincidência consigo mesmo. "A estrutura do herói dado na coexistência e na simultaneidade de contrários consolida a verossimilhança interna. A essa estrutura pode juntar-se o entrecruzamento de entonações diferentes na voz do narrador, a fim de que se consolide a experimentação da verdade e a carnavalização interna para a construção do herói e do autor" (DISCINI: 2006). Todas essas funções, conjuntamente, viabilizando a polifonia.

\section{Euforias e disforias de Alexei Ivanovitch}

O sujeito narrativo (no caso aqui Alexei), é um ser dominado pelas paixões da falta. Tenta, então, em seu afã em direção à completude, entrar em conjunção com um objeto de valor. Mas o querer de Alexei é ambivalente, se por um lado: "Preciso de dinheiro para mim mesmo e não me imagino uma função do capital" (disforiza o domínio da cultura, aqui entendida como coerção social), por outro quer também ser reconhecido como um homem de prestígio social, principalmente aos olhos de Paulina Alexandrovna. Com Paulina o sujeito confirma os sentimentos confusos, sente ora amor ora ódio por ela, porém quer obtê-la e até mesmo sente que deve obtê-la, pois do contrário crê que a própria vida dele não constitui valor (a idéia do suicídio é um tropo da poética de Dostoievski). O narrador chega mesmo a declarar-lhe que se jogaria de um precipício se assim ela desejasse.

Alexei quer e crê querer saber o que fazer para entrar em conjunção com os objetos valorizados: dinheiro, objeto de valor descritivo. Quer o dinheiro para impressionar Paulina, deixar de ser, segundo ele crê, um "zero à esquerda", um "escravo". Alexei aceita a manipulação social de que o dinheiro pode comprar a dignidade e a estima de alguém (valor esse euforizado pelos atores do âmbito do limite). Alexei é seduzido pela imagem positiva socialmente dada, do homem de status, contrária à imagem negativa de "escravo". Alexei também é tentado pelo prêmio do prestígio.

Então, apesar de seus discursos e atos, Alexei aceita a manipulação da aparência social? Do parecer ser? Do prestígio social? Observemos este trecho, em que Alexei já está arruinado pelo jogo e sem Paulina: "numa única volta da roleta tudo pode 
mudar (...) Não me evitarão mais como fazem no momento. Mas eu cuspo em todos esses sujeitos. Quem sou eu no momento? Um zero. Que posso ser amanhã? Posso ressuscitar dos mortos e recomeçar a viver. Posso descobrir o homem em mim, antes que esteja perdido". Alexei não aceita, no modo do ser, a manipulação feita pela sociedade em função do objeto de valor prestígio social e sucesso. Quer ressuscitar do mundo dos mortos (lugar onde ninguém se diferencia) e começar a viver. Se constituir como um homem vivo no mundo (mas o próprio mundo de Alexei é o inferno carnavalesco cotidianizado). Alexei continua transgredindo os valores sociais até o fim da narrativa, continua a jogar na roleta. No trecho agora citado há também um tropo comum da poética de Dostoiévski: tudo pode ser destruído e refeito em um minuto. Temos a isotopia da metamorfose contínua da vida, a fundar a polifonia discursivamente. Alexei, no discurso, tem papéis temáticos do hesitante.

Quando Paulina aparece no quarto de Alexei, "inteira", ele a faz esperar e vai tentar se enriquecer na roleta, fato que realmente acontece. Os dois têm uma noite juntos, porém, como já indicara Mr. Astley, o amigo inglês de Alexei, este gastaria toda a sua fortuna em Paris, deixando Paulina Alexandrovna aos cuidados daquele. Depois de se entediar em Paris gastando toda a sua fortuna com champanhe, festas, e com a senhorita Blanche, que não se cansava de comprar objetos do jogo da aparência social (e mesmo assim Alexei não goza do amor sensual com Blanche, um outro homem o faz por ele) Alexei torna-se um pequeno jogador de roleta, e perde dinheiro, amigos, Paulina, seu trabalho... Chegando a ser até preso uma vez, temos um ator dado nas viravoltas da vida, para que se confirme como polifônico. No fim da narrativa esse ator se encontra com Mr. Astley, que lhe avisa que Paulina ainda o ama, mas, nas palavras do inglês, Alexei "está perdido (...) sua vida está acabada".

Alexei não possui o reconhecimento de grande homem, acima dos valores sociais, pelos outros personagens. Cabe então uma reflexão sobre a oposição identidade $x$ alteridade:

"A soma dos dois termos, alteridade e identidade, pode gerar um termo complexo, a pessoalização, ou individualização, a construção da pessoa, ou do indivíduo, que supõe a reunião paradoxal dessas forças contrárias" (DISCINI: 2004, p. 84).

\section{As paixões ${ }^{10}$}

Alexei torna-se realizado ao tomar como objeto de valor a vitória no jogo de roleta? Na verdade ele ainda sonha conseguir a consideração de Paulina (mesmo sabendo que talvez ela o ame), o prestígio em relação aos outros e ainda se vê como um sujeito em falta, pois: "É preciso provar a eles". Dá-se então na ordem das paixões um sujeito angustiado, definido pela falta, em oposição à serenidade: paixão pela completude. Não importa o objeto de valor buscado por Alexei, ele está sempre em falta. Da dor sentida quando se está no pólo tensivo ao tédio do relaxamento da integração: "A vontade é em si mesma uma infelicidade fundamental: é insatisfação, esforço em vista de algo, inteligência, sede ardente, cobiça, desejo, sofrimento. É que, se tornando mundo, segundo o principio de individuação, pela sua fragmentação na multiplicidade, a vontade esquece a unidade primitiva e, não obstante todo o seu 
esmigalhamento, continue una, torna-se uma vontade que está milhões de vezes em luta consigo mesma, que se combate e se desconhece a si própria, que, em cada uma de suas manifestações, procura seu bem estar, seu 'lugar ao sol', às expensas de outra e, ainda mais, às expensas de todas as outras, não cessando, pois, de morder a própria carne, como aquele habitante do Tártaro que, avidamente, devorava a si mesmo"(Mann: 1941. Págs. 16-17).Alexei não nega a vontade, potencializa-a.

"Na base as variações temático-narrativas. No mito bíblico a desobediência que leva à morte, já que a passa ter a morte como termo, (...) a desobediência leva a morte, já que o transgressor é morto" (DISCINI: 2005, p. 264).

Mas aqui em Dostoiévski a própria morte é negada, a personagem vive, pois não há modo de reconciliação num mundo onde o ser é cada vez mais fragmentado, impotente perante a história. O herói incorpora o processo histórico, não possui competência para uma efetiva participação na história e na vida social pela crescente fragmentação do ser humano diante dos processos do capital, da burocracia, da industria cultural, na política sente seus direitos, poderes, usurpados por parte de seus representantes: coisas, dinheiro, idéias (ideologias), indústrias, imperam ante $o$ indivíduo: coisificação. Diante destes processos o indivíduo perde seu poder de atuação e é privado de se constituir como pessoa, eis o porquê de Alexei buscar reconhecimento, ele quer se constituir como pessoa (ter personalidade), como sujeito, como um ser no mundo, mas isso mesmo lhe é negado pela constante mecanização, pela indústria da massificação, em que tudo é feito para todos e na verdade para ninguém. A personalização é algo muito difícil em uma sociedade massificada.

O herói agora continua incansavelmente enchendo o tonel das Danaides, e no fundo a esperança: "Amanhã, amanhã tudo acabará!11..." (mais uma vez a ambigüidade se faz presente: tudo acabará possibilita uma dupla interpretação: ou ele tem esperança de sair de sua situação, ou ele recusa a opinião do senso comum de que a melhora vem com o amanhã. A última palavra de um herói polifônico não pode se dar na completude).

"Morreu a pior morte, a morte que pode repetir-se todos os dias e muitas vezes no mesmo dia" (DISCINI: 2004, p. 176).

\section{Conclusão}

Demonstra-se a possibilidade de uma análise e descrição da polifonia a partir do quadro teórico e metodológico da Semiótica e da Análise do Discurso de linha francesa, no romance de Dostoiévski. Ora, se se predica que os sujeitos na enunciação são alterados por queres, deveres, poderes e saberes, um sujeito em falta, em busca, tal como o é Alexei, certamente fundará a narrativa polifônica, certamente se prestará como exemplar de um modo próprio de dizer, o modo de Dostoiévski, que discorre sobre o mundo por meio da polifonia. Consideraremos uma representação da realidade e, através dela, tentaremos refletir sobre a própria realidade, por meio da observação dos mecanismos de construção dos textos e, conseqüentemente, de nós mesmos. 


\section{REFERÊNCIAS BIBLIOGRÁFICAS}

BAKHTIN, Mikhail (1981). Problemas da poética de Dostoievski. Rio de Janeiro: Ed. Forense Universitária.

DISCINI, Norma (2005). A comunicação nos textos. São Paulo: Contexto.

Carnavalização. In: BRAIT, Beth (2006). Bakhtin: outros conceitos chave. São Paulo: Edusp, p.53-97.

DOSTOIÉVSKI, fedor (1976). Os irmãos Karamazov. Leningrado: Ed. Naúka, (1998). O jogador. Porto Alegre: L\&PM editores.

MANN, Thomas. O pensamento vivo de Schopenhauer. São Paulo: Livraria Martins Editora (1941).

ROSENFELD, Anatol (2002). O teatro épico. Editora perspectiva

SAMOSÁTA, Luciano de (1996). Diálogo dos mortos. São Paulo: Edusp

\section{ANEXO}



A sociedade manipula Alexei para que ele queira e deva entrar em conjunção com o objeto valor prestígio social, a fim de obter o reconhecimento da própria sociedade.

Alexei quer e deve. Mas não sabe nem pode. Performance não realizada, Alexei não alcança o reconhecimento.

Este é um dos percursos narrativos do sujeito Alexei.

Paralelo a este, Alexei se automanipula para entrar em conjunção com a liberdade: quer, deve, sabe e pode: performance em consonância com a própria liberdade; na sanção um auto-reconhecimento.

Aí está a ambigüidade narrativa do percurso do sujeito Alexei.

Em $O$ jogador não há apenas uma voz de destinador manipulador, a ambigüidade está condizente com o romance polifônico: há um (manipulador) que propõe objeto de valor prestígio social e outro, que propõe a liberdade. Assim se delineia no nível narrativo um romance carnavalesco: é na roleta, onde, diante das forças do acaso, as pessoas se igualam, que se concretiza a sanção das ações do destinatário manipulado: a vitória ou a derrota, estas também ambíguas. Assim é dada pelo destinador manipulador sanções distintas.

Está implícito nessas manipulações a venda de valores, os quais, recordemos, Alexei circula. 
$\mathrm{S} 1 \longrightarrow \mathrm{S} 2 \quad \mathrm{O} \mathrm{Ov}=$ conquistas no jogo da roleta

$\mathrm{S} 1 \rightarrow \mathrm{S} 2 \mathrm{U}$ Ov $=$ conquistas no jogo da roleta

$\cap=$ conjunção - sujeito modalizado - quer e deve

$\mathrm{U}=$ disjunção - sujeito que não quer e não deve entrar em conjunção com o objeto de valor

Ov $=$ Objeto de valor

$\mathrm{S} 1=$ atores $\mathrm{A}$ (destinadores manipuladores $\mathrm{A})$

S2 = Alexei, que sofre manipulações ambíguas

Observação: Temos, em S1 um arqui-destinador actante, que é abstração narrativa, tanto aquele que manipula Alexei para jogar roleta quanto aquele que manipula Alexei para não jogar roleta.

\section{Como citar este artigo:}

SERPA, Danilo Chiovatto. Mecanismos de construção da polifonia na obra $O$ jogador de Dostoievski. Estudos Semióticos, Número 3, São Paulo, 2007. Disponível em <www.fflch.usp.br/dl/semiotica/es $>$. Acesso em "dia/mês/ano".

\footnotetext{
1 Em alemão fundamento é Grundlage, Grund é motivo, razão, causa, solo, chão, terreno, base, fundamento, fundo; Abgrund é abismo (ora, abismo é aquilo que é sem fundo), ou seja, em uma sociedade democrática o último fundamento não tem fundo, não pode ser fundamentado.

${ }^{2}$ Sublinhado nosso.

${ }^{3}$ Rei frígio que, segundo lenda, possuía o poder de transformar tudo o que tocava em ouro.

${ }^{4}$ Rei da Lídia famoso por suas riquezas.

${ }^{5}$ Rei da Lídia com fama de libertino e efeminado.

${ }^{6}$ Monge

7 “A menipéia é o gênero universal das últimas questões. Nela a ação não ocorre apenas 'aqui' e 'agora' mas em todo mundo e na eternidade” (BAKHTIN: 1981, p.127).

8 "O inferno cotidianizado contribui para a representação do destronamento dos poderosos" (DISCINI: 2006).

9 "Ocorre que com dinheiro me tornaria outro homem, mesmo aos seus olhos, e deixaria de ser um escravo". Dostoiévski, Fedor. O jogador, L\&PM editores, 1998. Pág 45

10 "Paixão é entendida como efeito de sentido, dado pela combinação de modalidades do ser”. Discini, Norma. A comunicação nos textos, Contexto, 2005. Pág 251

${ }^{11}$ Ultimas palavras do romance "O jogador".
} 